\title{
AKTSAR
}

ISSN 2622-5255 (online)

\section{Pengaruh Pengungkapan Islamic Social Reporting (ISR) terhadap Kinerja Keuangan pada Perbankan Syariah di Indonesia Tahun 2012-2016}

\author{
Susi Retnaningsih \\ Universitas Setia Budi Surakarta \\ Widi Hariyanti \\ Universitas Setia Budi Surakarta \\ Titiek Puji Astuti \\ Universitas Setia Budi Surakarta \\ titiekpujiastuti@gmail.com
}

\begin{abstract}
This study aims to examine the influence of Islamic Social Reporting (ISR) disclosure on financial performance. The dependent variable used in this research is financial performance measured by Return on Asset (ROA) and Return on Equity (ROE). The independent variable in this research is The Islamic Social Reporting (ISR). This study uses firm size as a control variable. The population in this study is the sharia banking industry registered in the Financial Services Authority (OJK) period 2012-2016. The sample in this research is 10 Sharia banks chosen by using a purposive sampling method. This study uses simple linear regression analysis as an analytical tool. The results showed that: (1) disclosure of Islamic Social Reporting (ISR) has a significant positive effect on Return on Assets (ROA). (2) disclosure of Islamic Social Reporting (ISR) has a significant positive effect on Return on Equity (ROE).
\end{abstract}

Keywords: Retun on Asset (ROA); Return on Equity (ROE); Islamic Social Reporting (ISR); Sharia Bank 


\begin{abstract}
ABSTRAK
Penelitian ini bertujuan untuk menguji pengaruh pengungkapan Islamic Social Reporting (ISR) terhadap kinerja keuangan. Variabel dependen yang digunakan dalam penelitian ini adalah kinerja keuangan yang diukur dengan Return on Asset (ROA) dan Return on Equity (ROE). Variabel independen dalam penelitian ini adalah Islamic Social Reporting (ISR). Populasi dalam penelitian ini adalah industri perbankan syariah yang terdaftar di Otoritas Jasa Keuangan (OJK) periode 2012-2016. Sampel dalam penelitian ini adalah 10 bank syariah yang dipilih dengan menggunakan metode purposive sampling. Penelitian ini menggunakan analisis regresi linier sederhana sebagai alat analisis. Hasil penelitian menunjukkan bahwa: (1) pengungkapan Islamic Social Reporting (ISR) berpengaruh positif signifikan terhadap Return on Asset (ROA). (2) pengungkapan Islamic Social Reporting (ISR) berpengaruh positif signifikan terhadap Return on Equity (ROE)
\end{abstract}

Kata kunci: Retun on Asset (ROA); Return on Equity (ROE); Islamic Social Reporting (ISR); Bank Syariah

\title{
PENDAHULUAN
}

Pada dasarnya, setiap perusahaan memiliki tujuan utama yaitu untuk memperoleh laba yang maksimal. Pada era globalisasi ini, persaingan antar perusahaan yang semakin ketat, menuntut perusahaan untuk menghadapi dan mengantisipasi segala situasi agar mampu bertahan dan tetap maju di tengah situasi tersebut. Seperti halnya industri keuangan syariah yang dianggap sebagai industri yang sangat berpeluang di Indonesia. Mengingat populasi masyarakat muslim di Indonesia menduduki posisi terbesar, maka industri keuangan syariah dianggap sebagai industri yang sangat berpeluang di Indonesia. Sedangkan dari sisi nasabah, saat ini jumlah total nasabah masih sekitar 8,8 persen dari total penduduk Indonesia. Untuk dapat meraih peluang yang sangat besar itu lembaga keuangan syariah harus melakukan penguatan kelembagaan keuangan syariah, yaitu mulai dari permodalan, keterbatasan SDM dan soal tata kelola yang baik. Dimana Corporate Social Responsibility (CSR) merupakan salah satu faktor yang menunjukkan baik atau tidaknya tata kelola perusahaan tersebut (replubika.co.id).

Kinerja keuangan diartikan sebagai penentuan ukuran-ukuran tertentu yang dapat mengukur keberhasilan suatu perusahaan dalam menghasilkan laba. Dalam mengukur kinerja keuangan perlu dikaitkan antara perusahaan dengan pusat pertanggungjawaban (Ermayanti, 2009). Seperti halnya perbankan syariah, sebagai lembaga yang penting dalam perekonomian, maka perlu adanya pengawasan kinerja yang baik oleh regulator perbankan. Kegiatan usaha perbankan syariah pada dasarnya merupakan perluasan jasa perbankan bagi masyarakat yang membutuhkan 
dan menghendaki pembayaran imbalan yang tidak didasarkan pada sistem bunga, melainkan atas dasar prinsip syariah sebagaimana digariskan syariah (hukum) Islam. perbankan syariah dikatakan sebagai suatu sistem yang menyandarkan pada kesinambungan pertumbuhan ekonomi, dapat tumbuh dan mencapai kinerja yang relatif baik seiring dengan pertumbuhan dan stabilnya perekonomian nasional (Haniffa dan Hudaib, 2007).

Menurut Rosiliana dan Yuniarta (2014) penerapan Corporate Social Responsibility (CSR) dipercaya dapat meningkatkan kinerja keuangan perusahaan, dimana investor cenderung menanamkan modal pada perusahaan yang melakukan aktivitas CSR. Karena bagi investor, perusahaan yang melakukan aktivitas CSR berpotensi menghasilkan laba yang lebih besar dibandingkan yang tidak, sehingga ke depannya perusahaan akan mampu meningkatkan kinerja keuangannya. Teori tersebut terasa kurang menekankan nilai sosial dan lebih menekankan nilai materialistik. Memang literatur yang ada menegaskan bahwa komitmen untuk melaksanakan CSR pada saatnya akan mengakibatkan kinerja yang lebih baik dalam hal profitabilitas, daya saing dan manajemen resiko. Berbeda dengan teori-teori barat, Ahmad (2002) menjelaskan pandangan Islam tentang CSR mengambil pendekatan yang lebih holistik. Menawarkan pemandangan spiritual integralistik berdasarkan ajaran Al-Quran dan Sunnah, serta menyediakan kerangka filosofis alternatif yang lebih baik untuk interaksi manusia dengan alam sesamanya.

Seiring dengan adanya tren global akan praktik CSR, meskipun praktik CSR lebih banyak dilakukan oleh perusahaan tambang dan manufaktur, industri perbankan juga telah menuliskan aspek pertanggungjawaban sosial dalam laporan tahunannya walaupun dalam bentuk yang relatif sederhana. Pengungkapan tersebut tidak hanya dilakukan oleh perbankan konvensional tetapi juga oleh perbankan syariah. Konsep CSR kini tidak hanya berkembang di ekonomi konvensional, tetapi juga berkembang dalam ekonomi Islam. konsep CSR dalam Islam erat kaitannya dengan perusahaan-perusahaan yang menjalankan kegiatan bisnis sesuai dengan konsep Syariah yang diharapkan perusahaan tersebut dapat melakukan tanggung jawab sosial perusahaan secara islami (Fitria dan Hartanti, 2010).

Di Indonesia, semakin banyak perusahaan-perusahaan yang berbasiskan syariah bermunculan, hal ini mengindikasikan bahwa ekonomi Islam sedang mengalami perkembangan yang cukup pesat. Oleh karena itu, untuk memenuhi pelaporan yang berbasiskan syariah maka umat muslim mulai mengembangkan pelaporan tanggung jawab sosial perusahaan yang sesuai dengan prinsip syariah yang dikenal dengan Islamic Social Reporting (ISR). Pengungkapan ISR merupakan penyempurnaan dari pengungkapan CSR yang menambahkan beberapa item yang tidak terdapat di dalam pengungkapan CSR (Widiawati, 2012).

Pertumbuhan bank syariah di Indonesia mendorong lahirnya etika pengungkapan tanggung jawab sosial. Sebagai entitas yang berbasis Islam, sudah sepatutnya bank syariah memperhatikan lingkungan dan masyarakat sekitar sebagai bentuk kepedulian dan tanggung jawab terhadap umat. Sesuai dengan UU No. 21 Tahun 2008 pasal 7 "bentuk badan hokum bank syariah adalah Perseroan Terbatas", sehingga dalam hal tanggung jawab sosial dan lingkungan, bank syariah harus mengacu pada UU No.40 Tahun 2007 pasal 74 tentang Perseroan Terbatas (PT). 
Terkait dengan adanya kebutuhan mengenai pengungkapan tanggung jawab sosial di sektor syariah atau yang dikenal Islamic Social Reporting (ISR). Accounting and Auditing Organization for Islamic Financial Institutions (AAOIFI) yang merupakan organisasi internasional yang berwenang dalam penetapan standar akuntansi, audit, tata kelola, dan etika syariah untuk institusi keuangan syariah di dunia telah menetapkan item-item ISR, yang kemudian dikembangkan lebih lanjut oleh para peneliti (Rosiana, dan Muhammad 2015). Indeks ISR diyakini dapat menjadi pijakan awal dalam hal standar pengungkapan CSR yang sesuai dengana ajaran Islam.

Indeks ISR pertama kali dikembangkan oleh Haniffa (2002) yang kemudian dikembangkan oleh Othman $d k k$. (2009). Haniffa (2002) menyatakan bahwa terdapat keterbatasan pada kerangka pelaporan sosial yang dilakukan oleh lembaga keuangan konvensional sehingga ia mengemukakan kerangka konseptual Islamic Social Reporting. Islamic Social Reporting (ISR) adalah hal yang penting bagi perbankan syariah untuk memperhatikan kepada masyarakat mengenai kepatuhan bank dalam menjalankan prinsip syariah (Khoirudin, 2013). Pelaporan sosial syariah atau Islamic Social Reporting (ISR) masih bersifat sukarela (voluntary) karena belum adanya standar baku dari pemerintah. Berbeda dengan CSR yang sudah bersifat wajib (mandatory) dengan dikeluarkannya Undang-Undang No 40 Tahun 2007 tentang Persetoan Terbatas (PT) bahwa laporan tahunan harus memuat beberapa informasi, salah satunya adalah laporan pelaksanaan tanggung jawab sosial dan lingkungan. Sayangnya CSR belum sepenuhnya dapat mengungkapkan informasi tentang tanggung jawab sosial secara menyeluruh termasuk didalamnya tentang tema syaraih. Jadi, perlu adanya ISR yang masih bersifat sukarela (voluntary) menyebabkan pelaporan masing-masing entitas syariah menjadi berbeda (Jannah dan Asrori, 2016).

\section{TINJAUAN LITERATUR}

\section{Teori Legitimasi}

Teori legitimasi merupakan salah satu teori yang banyak dikutip dalam area akuntansi lingkungan dan sosial (Tilling, 2004). Lebih lanjut, Hadi (2011) menyatakan, legitimasi masyarakat merupakan faktor strategi bagi perusahaan dalam rangka mengembangkan perusahaan ke depan. Legitimasi dapat dijadikan sebagai wacana untuk mengkonstruksi strategi perusahaan, terutama terkait dengan upaya memposisikan diri keberpihakan perusahaan di tengah lingkungan masyarakat. Penerimaan yang baik dari masyarakat dapat membantu perusahaan dalam mencapai tujuannya, sehingga dapat menjamin kelangsungan hidup perusahaan.

Teori legitimasi menganjurkan perusahaan untuk meyakinkan bahwa aktivitas dan kinerjanya dapat diterima oleh masyarakat. Perusahaan menggunakan laporan tahunan mereka untuk menggambarkan kesan tanggung jawab lingkungan, sehingga mereka diterima oleh masyarakat. Dengan adanya penerimaan dari masyarakat tersebut diharapkan dapat meningkatkan nilai perusahaan sehingga dapat meningkatkan laba perusahaan. Hal tersebut dapat mendorong atau membantu investor dalam melakukan pengambilan keputusan investasi (Harsanti, 2011).

Penggunaan teori legitimasi dalam penelitian ini memiliki implikasi bahwa program ISR dilakukan perusahaan dengan harapan untuk mendapatkan nilai positif dan legitimasi dari masyarakat. Ini berarti apabila perusahaan mendapatkan legitimasi dari masyarakat, maka perusahaan dapat terus bertahan dan berkembang 
di tengah-tengah masyarakat serta mendapatkan keuntungan pada masa yang akan datang.

\section{Teori Stakeholders}

Teori stakeholder mengatakan bahwa perusahaan bukanlah entitas yang hanya beroperasi untuk kepentingan sendiri, namun harus mampu memberikan manfaat bagi stakeholdernya (Ghozali dan Chariri, 2007). Lebih lanjut, Ghozali dan Chariri (2007) menyatakan bahwa kelangsungan hidup perusahaan tergantung pada dukungan stakeholder dan dukungan tersebut harus dicari sehingga aktivitas perusahaan adalah untuk mencari dukungan tersebut.

Stakeholder adalah pihak-pihak yang berkepentingan pada perusahaan dan dapat mempengaruhi aktivitas perusahaan, seperti masyarakat, karyawan, pemerintah, supplier, pasar modal, dan lain-lain (Gray dkk., 2001). Menurut Wibisono (2007), apapun definisinya, antara stakeholder dengan perusahaan terjadi hubungan yang saling mempengaruhi, sehingga perubahan pada salah satu pihak akan memicu dan mendorong terjadinya perubahan pada pihak lainnya. Menurut Heal dan Garret (2004) menunjukkan bahwa aktivitas CSR dapat menjadi elemen yang menguntungkan sebagai strategi perusahaan, memberikan kontribusi kepada manajemen risiko dan memelihara hubungan yang dapat memberikan keuntungan jangka panjang perusahaan, sehingga berdasarkan teori stakeholder peneliti menduga bahwa terdapat pengaruh ISR terhadap kinerja keuangan perusahaan.

\section{Islamic Social Reporting (ISR)}

CSR merupakan pendekatan yang seimbang bagi organisasi untuk mengatasi ekonomi, sosial dan isu lingkungan dengan cara yang menguntungkan orang, dan masyarakat. Dalam perspektif Islam, CSR merupakan realisasi dari konsep ajaran ihsan sebagai puncak dari ajaran etika yang sangat mulia. Ihsan merupakan melaksanakan perbuatan baik yang dapat memberikan kemanfaatan kepada orang lain demi mendapatkan ridho Allah SWT. Disamping itu, CSR merupakan implikasi dari ajaran kepemilikan dalam Islam, Allah adalah pemilik mutlak (haqiqiyah) sedangkan manusia hanya sebatas pemilik sementara (temporer) yang berfungsi sebagai penerima amanah. (Dzakfar, 2007)

Sejalan dengan semakin meningkatnya pelaksanaan CSR dalam konteks Islam, maka semakin meningkat pula keinginan untuk membuat pelaporan sosial yang bersifat syariah (Islamic Social Reporting atau ISR). Ada dua hal yang harus diungkapkan dalam perspektif Islam, yaitu pengungkapan penuh (full disclosure) dan akuntabilitas sosial (social accountability) (Fitria dan Hartanti, 2010). Islam telah menjelaskan cukup jelas mengenai hak dan kewajiban bagi individu maupun bagi organisasi berdasarkan Al-Quran dan Hadits. Hal tersebut dikarenakan Islam adalah agama yang secara lengkap mengatur seluruh aspek kehidupan manusia di muka bumi.

ISR pertama kali digagas oleh Ross Haniffa pada tahun 2002 dalam tulisannya yang berjudul "Social Reporting Disclosure: ISR lebih lanjut dikembangkan secara lebih ekstensif oleh Rohana Othman, Azlan Md Thani, dan Erlane K Ghani pada tahun 2009 di Malaysia dan saat ini ISR masih terus dikembangkan oleh peneliti-peneliti selanjutnya. Menurut Haniffa (2002) terdapat 
banyak keterbatasan dalam pelaporan sosial konvensional, sehingga ia mengemukakan kerangka konseptual ISR yang berdasarkan ketentuan syariah. ISR tidak hanya membantu pengambilan keputusan bagi pihak muslim melainkan juga untuk membantu perusahaan dalam melakukan pemenuhan kewajiban terhadap Allah dan masyarakat.

ISR adalah standar pelaporan kinerja sosial perusahaan-perusahaan yang berbasis syariah. Indeks ini lahir dan dikembangkan dengan dasar dari standar pelaporan berdasarkan AAOIFI yang kemudian dikembangkan oleh masing-masing peneliti berikutnya. Secara khusus indeks ini adalah perluasan dari standar pelaporan kinerja sosial yang meliputi harapan masyarakat tidak hanya mengenai peran perusahaan dalam perekonomian, tetapi juga peran perusahaan dalam perspektif spiritual. Selain itu indeks ini juga menekankan pada keadilan sosial terkait mengenai lingkungan, hak minoritas, dan karyawan (Fitria dan Hartati, 2010).

Indeks ISR adalah item-item pengungkapan yang digunakan sebagai indikator dalam pelaporan kinerja sosial institusi bisnis syariah. Pengungkapan ISR dapat diidentifikasi dengan menggunaka indeks ISR. Sejalan dengan penelitian Raditya (2012), indeks ISR yang digunakan dalam penelitian ini diambil dari penelitianpenelitian sebelumnya yaitu, Haniffa (2002) membuat lima tema pengungkapan Indeks ISR, yaitu Tema Pendanaan dan Investasi, Tema Produk dan Jasa, Tema Karyawan, Tema Masyarakat, dan Tema Lingkungan Hidup. Kemudian dikembangkan oleh Othman dkk., (2009) dengan menambahkan satu tema pengungkapan yaitu tema Tata Kelola Perusahaan.

\section{Kinerja Keuangan Bank}

Laporan tahunan merupakan salah satu sumber informasi guna mendapatkan gambaran kinerja perusahaan (Hendra dkk., 2010). Pengertian kinerja perusahaan adalah hasil kerja yang dapat dicapai oleh seseorang atau kelompok orang dalam suatu perusahaan sesuai dengan wewenang dan tanggung jawab masing-masing dalam upaya pencapaian tujuan perusahaan secara legal, tidak melanggar hukum dan tidak bertentangan dengan moral dan etika (Rivai dan Basri, 2004). Pengukuran terhadap kinerja perusahaan diperlukan untuk mengetahui apakah kinerja perusahaan dapat dikatakan baik atau buruk. Pengukuran kinerja perusahaan menyediakan indikator-indikator untuk mengetahui bagaimana menjalankan suatu organisasi secara baik.

Selanjutnya, kinerja keuangan yang akan digunakan dalam penelitian ini yaitu Return on Assets (ROA), dan Return on Equity (ROE). Rasio keuangan ini dipilih dengan alasan merupakan hasil akhir sejumlah kebijakan dan keputusan yang diambil oleh perusahaan. Rasio ini penting untuk mengetahui sampai sejauh mana kemampuan perusahaan menghasilkan laba.

Return on Assets (ROA) merupakan rasio penunjang dalam menghitung rentabilitas bagi bank syariah. Rasio ini digunakan untuk mengukur keberhasilan manajemen dalam menghasilkan laba. ROA dihitung dengan membagi laba sebelum pajak dengan total asset. Semakin kecil rasio ini mengindikasikan kurangnya kemampuan manajemen bank dalam hal mengelola aktiva untuk meningkatkan pendapatan dan menekan biaya. ROA digunakan untuk mengukur kemampuan 
manajemen bank dalam memperoleh laba secara keseluruhan dari total aktiva yang dimiliki (Dendawijaya, 2009).

Return on Equity (ROE) merupakan rasio antara laba bersih terhadap total equity. Return on Equity sering disebut juga rate of return on Net Worth yaitu kemampuan perusahaan dalam menghasilkan keuntungan dengan modal sendiri, sehingga ROE ini ada yang menyebut rentabilitas modal sendiri. ROE digunakan untuk mengukur kemampuan modal disetor bank dalam mengahasilkan laba. Semakin besar rasio ini akan menunjukkan kemampuan modal disetor bank dalam menghasilkan laba bagi pemegang saham semakin besar. ROE mengindikasikan kemampuan bank dalam menghasilkan laba dengan menggunakan ekuitasnya. Kenaikan dalam rasio ini berarti terjadi kenaikan laba bersih dari bank yang bersangkutan dan selanjutnya kenaikan tersebut akan menyebabkan kenaikan harga saham bank (Dendawijaya, 2009).

\section{Pengembangan Hipotesis}

\section{Pengaruh pengungkapan ISR perusahaan terhadap ROA}

Berdasarkan teori stakeholders bahwa ketika perusahaan bertemu dengan berbagai macam harapan para stakeholder mereka akan lebih mampu menciptakan kinerja perusahaan yang luar biasa (Freeman, 1983). Menurut Anwar dan Alfattani (2014) kinerja keuangan menggambarkan peran dalam meningkatkan kegiatan yang ditawarkan oleh bank Islam kepada investor. Transformasi dari beberapa bank konvensional ke bank Islam telah menciptakan reputasi yang baik bagi investor melalui ISR yang baik.

Preston and Bannon (1997) lebih lanjut mengusulkan bahwa pertemuan para pemangku kepentingan utama (karyawan dan konsumen) dapat meningkatkan reputasi perusahaan dan memiliki dampak positif terhadap kinerja keuangan. Pendapat ini adalah kunci dari dampak hipotesis sosial, yang berarti bahwa kinerja sosial yang baik akan mengakibatkan kinerja keuangan yang baik dan keduanya memiliki pengaruh positif.

Penelitian terdahulu tentang pengaruh pengungkapan pertanggungjawaban sosial secara Islam terhadap kinerja keuangan yang diukur dengan ROA telah dilakukan oleh Harahap dan Siregar (2017) dan Dawam (2016). Dari hasil penelitian tersebut diperoleh bukti empiris bahwa pengungkapan pertanggungjawaban sosial perusahaan berpengaruh positif terhadap ROA.

Berdasarkan uraian diatas, maka hipotesis dalam penelitian ini adalah:

\section{H1 : Pengungkapan ISR berpengaruh positif terhadap ROA.}

\section{Pengaruh pengungkapan ISR perusahaan terhadap ROE}

Berdasarkan teori legitimasi bahwa perusahaan melakukan program ISR untuk mendapatkan nilai positif dan legitimasi dari masyarakat karena legitimasi masyarakat merupakan faktor strategi bagi perusahaan dalam rangka mengembangkan perusahaan ke depan. Pengungkapan ISR merupakan salah satu strategi perusahaan untuk mencapai tujuan perusahaan. Dengan melakukan pengungkapan ISR perusahaan akan mendapatkan citra baik dan kepercayaan dari masyarakat dan nantinya mampu menimbulkan loyalitas konsumen. Loyalitas 
konsumen akan meningkatkan penjualan yang berdampak pada kenaikan laba. Selain menghitung profitabilits dengan ROA, perhitungan lain yang juga sering digunakan ada ROE. ROE adalah rasio profitabilitas yang menunjukkan perbandingan antara laba (setelah pajak) dengan modal (Khairunnisa, 2010).

Menurut Watt dan Zimmerman (1986, dalam Widiawati dan Raharja, 2012), perusahaan dengan profit yang lebih tinggi memiliki kecenderungan untuk melakukan intervensi kebijakan. Oleh karena itu, perusahaan tersebut akan terdorong untuk mengungkapkan informasi yang lebih rinci dalam laporan tahunan mereka. Semakin besar ROE, semakin besar pula tingkat keuntungan yang dicapai bank sehingga kemungkinan suatu bank dalam kondisi bermasalah semakin kecil dengan begitu bank akan cenderung mengungkapkan laporan tahunannya dengan lebih baik, termasuk peningkatan pengungkapan laporan tanggung jawab sosialnya.

Penelitian terdahulu mengenai pengaruh pengungkapan ISR terhadap kinerja keuangan yang diukur dengan ROE telah dilakukan oleh Wardani (2016) dan Riswanti (2017). Dari hasil penelitian tersebut diperoleh bukti empiris bahwa pengungkapan ISR berpengaruh positif terhadap ROE.

Berdasarkan uraian diatas maka hipotesis dalam penelitian ini adalah:

\section{H2 : Pengungkapan ISR berpengaruh positif terhadap ROE.}

\section{METODE}

\section{Metode Penelitian}

Penelitian ini merupakan penelitian kuantitatif dengan paradigma penelitian positivistik. Penelitian ini bertujuan untuk mengetahui pengaruh ISR terhadap kinerja perbankan syariah dengan ROA dan ROE sebagai proksinya. Data yang digunakan dalam penelitian ini adalah data sekunder. Teknik pengumpulan data dilakukan dengan mereview data keuangan dan laporan ISR bank syariah di Indonesia.

Populasi penelitian ini adalah seluruh bank syariah di Indonesia. Metode pemilihan sampel dalam penelitian ini adalah metode purposive sampling. Adapun kriteria yang digunakan dalam penentuan sampel penelitian ini adalah bank unum syariah yang terdaftar di OJK, bank umum syariah yang telah menerbitkan dan mempublikasikan laporan tahunan secara berturut-turut dari tahun 2012-2016, perusahaan yang mengungkapkan ISR dalam laporan tahunannya dan perusahaan yang menggunakan satuan nilai rupiah dalam laporan keuangannya. Atas dasar kriteria tersebut diperoleh jumlah sampel sebanyak 10 bank syariah dengan periode 2012-2016.

Metode analisis data menggunakan statistik deskriptif, uji asumsi klasik dan uji hipotesis. Statistik deskripstif memberikan gambaran atau deskripsi suatu data yang dilihat dari nilai rata-rata (mean), standar deviasi, maksimum, minimum. Untuk melakukan uji asumsi klasik atas data sekunder ini, maka peneliti melakukan uji normalitas, uji heteroskedastisitas, dan uji autokorelasi.

Uji hipotesis yang akan dilakukan dalam penelitian ini adalah Koefisien Determinasi, Uji Statistik t dan Uji Statistik F. Pengujian hipotesis dilakukan untuk melihat seberapa besar variabel independen tersebut mempengaruhi variabel dependen. Jika nilai signifikansi pada pengujian statistik $\mathrm{t}$ dan statistik $\mathrm{f}$ dibawah 0,05 maka hipotesis diterima dan sebaliknya. 


\section{Definisi Operasional Variabel}

Penelitian ini menggunakan variabel dependen kinerja keuangan yang diproksikan dengan ROA dan ROE.

Variabel ROA menunjukkan seberapa banyak laba bersih yang dapat diperoleh dari keseluruhan aset yang dimiliki oleh perusahaan. ROA dihitung dengan membagi laba laba usaha setelah pajak dengan total aset. ROE mengukur pengembalian atas ekuitas saham biasa atau tingkat pengembalian atas investasi pemegang saham, ROE dihitung dengan membagi laba setelah pajak dengan ekuitas.

Variabel independen dalam penelitian ini adalah pengungkapan ISR. Pada penelitian ini pengungkapan ISR diukur dengan menggunakan index pengungkapan sosial yang merupakan variabel dummy. Rumus perhitungan pengungkapan ISR adalah sebagai berikut;

$$
\boldsymbol{I S R D}_{\boldsymbol{j}}=\frac{\sum X_{I j}}{\boldsymbol{n}_{\boldsymbol{j}}}
$$

Keterangan:

$I S R D_{j}$ : Islamic Social Reporting Disclosure Index perusahaan $\mathrm{j}$

$\mathrm{Nj} \quad$ : jumlah item untuk perusahaan $\mathrm{j}, \mathrm{nj}=43$

Xij $\quad: 1=$ jika item i diungkapkan, $0=$ jika item I tidak diungkapkan. Sehingga $0 \leq 1 j \geq 1$.

Untuk mengukur seberapa jauh Bank Syariah menerapkan prinsip Islam yang baik dalam pengungkapan ISR maka penelitian ini akan menilainya berdasarkan model Islamic Social Reporting Index (ISR Index), terdiri dari 43 item yang merupakan tolak ukur pelaksanaan kinerja sosial perbankan syariah yang berisi kompilasi item-item standar yang ditetapkan oleh AAOIFI (Accounting and Auditing Organization for Islamic Financial Institution, 2002).

\section{Model Persamaan}

Penelitian ini menggunakan model linier sederhana. Model regresi linier sederhana ini digunakan untuk mengetahui pengaruh ISR terhadap ROA dan ISR terhadap ROE. Alat analisis dalam penelitian ini menggunakan perangkat lunak SPSS. Ada dua model persamaan regresi yang digunakan, yaitu:

$$
\mathbf{Y} 1=\mathrm{a}+\mathrm{b} 1 \mathrm{X}+\mathrm{e}
$$

\section{Dimana :}

$$
\begin{aligned}
& \mathrm{Y} 1=\text { ROA } \\
& \mathrm{a}=\text { konstanta } \\
& \mathrm{bi}=\text { slope } \\
& \mathrm{X}=\mathrm{ISR} \\
& \mathrm{e}=\text { residual }
\end{aligned}
$$

dan

$$
\mathrm{Y} 2=\mathrm{a}+\mathrm{b} 2 \mathrm{X}+\mathrm{e}
$$

Dimana :

$$
\begin{aligned}
& \mathrm{Y} 2=\mathrm{ROE} \\
& \mathrm{a}=\text { konstanta } \\
& \mathrm{bi}=\text { slope }
\end{aligned}
$$




$$
\begin{aligned}
& X=\text { ISR } \\
& \mathrm{e}=\text { residual }
\end{aligned}
$$

\section{HASIL DAN PEMBAHASAN}

\section{Statsistik Deskriptif}

Hasil Analisis Statistik Deskriptif pada Hubungan ISR dan ROA

Tabel 1. Hasil Analisis Statistik Deskriptif

\begin{tabular}{llllc}
\hline & Minimum & Maksimum & Mean & Std. Deviation \\
\hline ROA &,- 1075 &, 0312 &, 005434 &, 0210360 \\
ISR &, 3260 &, 7210 &, 544143 &, 0998021 \\
Valid & & & & \\
N(listwise) & & & & \\
\hline
\end{tabular}

Sumber: Data diolah tahun 2018

Berdasarkan Tabel 1 di atas nilai ROA minimum sebesar -0,1075 nilai maksimum sebesar 0,0312 dan sedangkan untuk nilai rata-rata (mean) sebesar 0,005435 dengan nilai standar deviasi sebesar 0,0210360. Rata-rata nilai ROA sebesar 0,005435 atau 0,54\%, hal ini menunjukkan bahwa dengan pengukuran ROA terdapat adanya kenaikan kinerja keuangan pada perusahaan selama periode pengamatan sebesar $0,54 \%$.

Variabel independen pengungkapan Islamic Social Reporting (ISR) menunjukkan bahwa nilai rata-rata (mean) sebesar 0,544143. Hal ini berarti bahwa rata-rata perusahaan perbankan syariah yang menjadi sampel telah mengungkapakan ISR sebesar 54,41\% yang artinya di dalam pengungkapan Islamic Social Reporting (ISR) terdapat 43 sub item pengungkapan artinya rata-rata setiap perusahaan perbankan mengungkapkan 23 sub item dari 43 sub item yang ada.

\section{Hasil Analisis Statistik Deskriptif pada Hubungan ISR dan ROE}

Tabel 2. Hasil Analisis Statistik Deskriptif

\begin{tabular}{lllll}
\hline & Minimum & Maksimum & Mean & Std. Deviation \\
\hline ROE &,- 3901 &, 2979 &, 036204 &, 1027294 \\
ISR &, 3260 &, 8140 &, 545460 &, 1165785 \\
N(listwise) & & & & \\
\hline
\end{tabular}

Sumber: Data diolah tahun 2018

Berdasarkan Tabel 2 di atas nilai ROE minimum sebesar -0,3901, nilai maksimum sebesar 0,2979 dan sedangkan untuk nilai rata-rata (mean) sebesar 0,036204 dengan nilai standar deviasi sebesar 0,1027294. Rata-rata nilai ROE sebesar 0,036204 atau $0,36 \%$, hal ini menunjukkan bahwa dengan pengukuran ROE terdapat adanya kenaikan kinerja keuangan pada perusahaan selama periode pengamatan sebesar $0,36 \%$.

Variabel independen pengungkapan Islamic Social Reporting (ISR) menunjukkan bahwa nilai rata-rata (mean) sebesar 0,545460. Hal ini berarti bahwa rata-rata perusahaan perbankan syariah yang menjadi sampel telah mengungkapakan 
ISR sebesar 54,54\%. Yang artinya didalam pengungkapan Islamic Social Reporting (ISR) terdapat 43 sub item pengungkapan artinya rata-rata setiap perusahaan perbankan mengungkapkan 24 sub item dari 43 sub item yang ada.

\section{Hasil Uji Asumsi Klasik}

\section{Hasil Uji Asumsi Klasik pada Hubungan ISR terhadap ROA}

Hasil uji normalitas berdasarkan hasil uji menggunakan pengujian one-sample kolmogorv-smirnov test yang telah dilakukan ini menunjukkan nilai Asym. Sig (2-tailed) sebesar 0,382 yang berarti nilai signifikansinya lebih besar atau di atas 0,05. Sehingga dapat disimpulkan bahwa data sampel yang akan diuji terdistribusi secara normal.

Hasil uji heteroskedastisitas berdasarkan pada Gambar 1 terlihat bahwa scatterplot datanya tersebar secara acak dan tidak membentuk suatu pola yang sistematis, sehingga dapat disimpulkan bahwa dalam pengujian heteroskedastisitas penelitian ini varian residualnya homogen dan model dalam penelitian ini dinyatakan bebas dari gejala heteroskedastisitas.

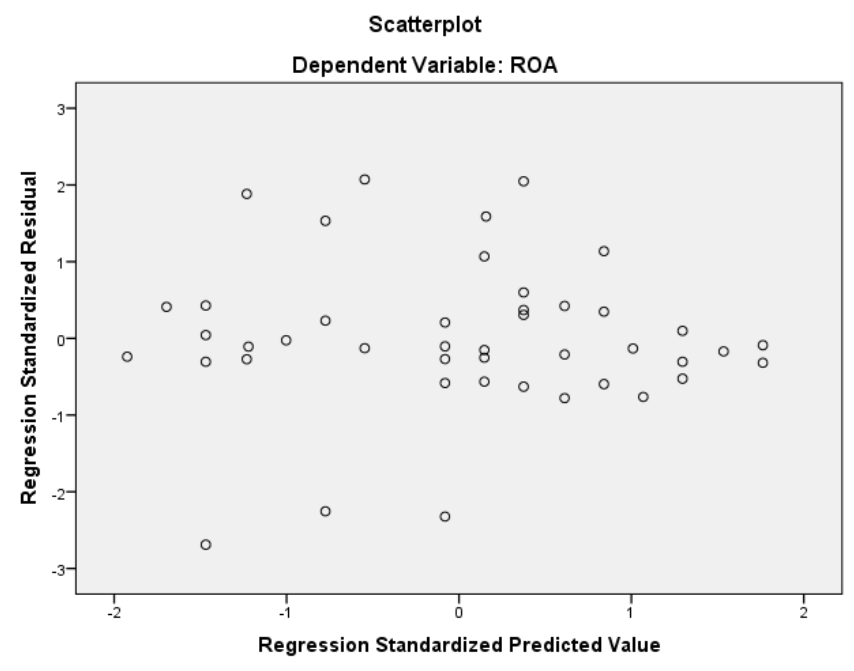

Sumber: Data diolah

Gambar 1. Hasil Uji Heteroskedastisitas

Hasil uji autokorelasi dengan menggunakan run test pada penelitian ini menunjukkan nilai Asym. Sig. (2-tailed) > 0,05 yaitu berada di nilai 0,274 sehingga dapat disimpulkan bahwa model dalam penelitian ini bebas dari gejala autokorelasi.

\section{Hasil Uji Asumsi Klasik pada Hubungan ISR terhadap ROE}

Hasil uji normalitas berdasarkan hasil uji menggunakan pengujian one-sample kolmogorv-smirnov test yang telah dilakukan ini menunjukkan nilai Asym. Sig (2-tailed) sebesar 0,241 yang berarti nilai signifikansinya lebih besar atau diatas 0,05. Sehingga dapat disimpulkan bahwa data sampel yang akan diuji terdistribusi secara normal.

Hasil uji heteroskedastisitas berdasarkan pada Gambar 2 terlihat bahwa scatterplot datanya tersebar secara acak dan tidak membentuk suatu pola yang sistematis, sehingga dapat disimpulkan bahwa dalam pengujian heteroskedastisitas penelitian ini varian residualnya homogen dan model dalam penelitian ini dinyatakan bebas dari gejala heteroskedastisitas. 


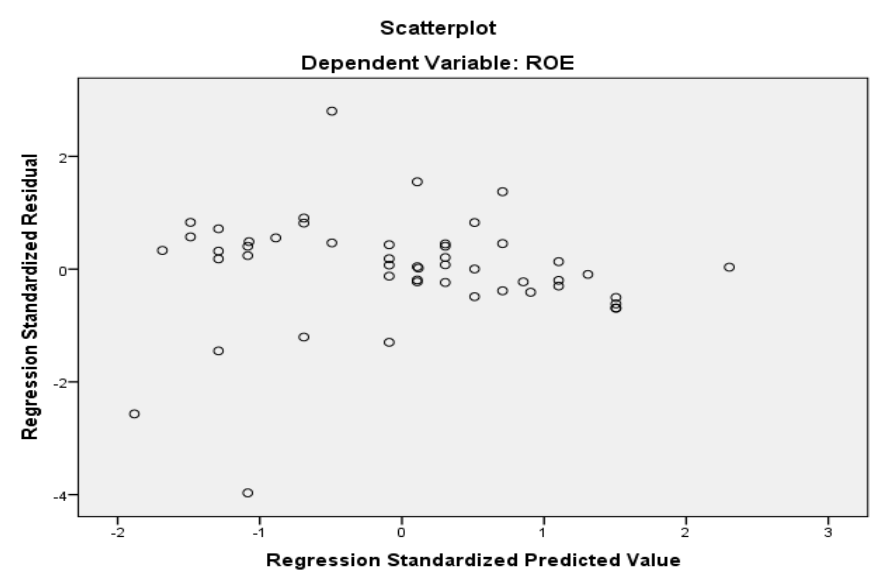

Sumber: Data diolah

Gambar 2. Hasil Uji Heteroskedastisitas

Hasil uji autokorelasi dengan menggunakan run test pada penelitian ini menunjukkan nilai Asym. Sig. (2-tailed) > 0,05 yaitu berada di nilai 0,253 sehingga dapat disimpulkan bahwa model dalam penelitian ini bebas dari gejala autokorelasi.

\section{Hasil Uji Hipotesis}

\section{Pengujian Kelayakan Model pada Hubungan ISR terhadap ROA}

Hasil pengujian menunjukkan bahwa nilai untuk variabel dependen yaitu Return on Assets (ROA) yang dapat dijelaskan oleh variabel independen (ISR) adalah sebesar $11,3 \%$ sedangkan sisanya yaitu sebesar $88,7 \%$ dijelaskan oleh variabel lain diluar model penelitian. Berikut tabel hasil pengujian koefisien determinasi:

Tabel 3. Hasil Uji Koefisien Determinasi

\begin{tabular}{ccccc}
\hline Model & R & R Square & $\begin{array}{c}\text { Adjusted R } \\
\text { Square }\end{array}$ & $\begin{array}{c}\text { Std. Error of } \\
\text { the Estimate }\end{array}$ \\
\hline 1 &, 337 &, 113 &, 091 &, 0200542 \\
\hline
\end{tabular}

Sumber: data diolah

Hasil uji statistik $\mathrm{t}$ dapat dilihat pada Tabel 4 dibawah ini. Berdasarkan Tabel 4 terlihat bahwa variabel independen berpengaruh terhadap variabel dependen yaitu bisa dilihat dari nilai signifikansi dari variabel ISR menunjukkan nilai sebesar 0,029 $(0,029<0,05)$, maka diterima dan tidak ditolak berarti variabel ISR berpengaruh signifikan positif terhadap ROA. Karena tingkat signifikansi variabel tersebut dibawah atau kurang dari 0,05.

Tabel 4. Hasil Uji Statistik $\mathrm{t}$

\begin{tabular}{|c|c|c|c|c|}
\hline Variabel & $\mathrm{B}$ & $\mathrm{T}$ & Sig. & Keterangan \\
\hline ISR & 0,071 & 2,261 & 0,029 & Signifikan \\
\hline
\end{tabular}

Sumber : data diolah 
Model persamaan regresi yang terbentuk adalah sebagai berikut :

$\mathrm{Y} 1=0.071 \mathrm{X}+\mathrm{e}$

\section{Pengujian Kelayakan Model pada Hubungan ISR terhadap ROE}

Hasil pengujian menunjukkan bahwa nilai untuk variabel dependen yaitu Return on Equity (ROE) yang dapat dijelaskan oleh variabel independen (ISR) adalah sebesar 9,2\% sedangkan sisanya yaitu sebesar 90,8\% dijelaskan oleh variabel lain diluar model penelitian. Berikut tabel hasil pengujian koefisien determinasi:

Tabel 5. Hasil Uji Koefisien Determinasi

\begin{tabular}{ccccc}
\hline Model & R & R Square & $\begin{array}{c}\text { Adjusted R } \\
\text { Square }\end{array}$ & $\begin{array}{c}\text { Std. Error of } \\
\text { the Estimate }\end{array}$ \\
\hline 2 &, 304 &, 092 &, 073 &, 0988899 \\
\hline
\end{tabular}

Sumber: data diolah

Hasil uji statistik t dapat dilihat pada Tabel 6 dibawah ini. Berdasarkan Tabel 6 terlihat bahwa variabel independen berpengaruh terhadap variabel dependen yaitu bisa dilihat dari nilai signifikansi dari variabel ISR menunjukkan nilai sebesar 0,032 $(0,032<0,05)$, maka diterima dan tidak ditolak berarti variabel ISR berpengaruh signifikan positif terhadap ROA. Karena tingkat signifikansi variabel tersebut dibawah atau kurang dari 0,05.

Tabel 6. Hasil Uji Statistik $t$

\begin{tabular}{lcrrr} 
Variabel & B & T & Sig. & Keterangan \\
\hline ISR & 0,268 & 2,209 & 0,032 & Signifikan \\
\hline
\end{tabular}

Sumber : data diolah

Model persamaan regresi yang terbentuk adalah sebagai berikut :

$$
Y 2=0.268 X+e
$$

\section{Pembahasan}

Pengujian Pengaruh Islamic Social Reporting (ISR) terhadap Return on Asset (ROA)

Hasil pengujian variabel menunjukkan bahwa variabel Islamic Social Reporting (ISR) mempunyai nilai signifikan sebesar 0,029 $(0,029<0,05)$ yang berarti bahwa variabel Islamic Social Reporting (ISR) berpengaruh signifikan positif terhadap Return On Asset (ROA). Hasil ini konsisten dengan hipotesis awal yang menyatakan 
variabel ISR berpengaruh positif signifikan terhadap ROA. Sehingga ISR dapat digunakan untuk memprediksi ROA dengan arah koefisien positif, artinya jika ISR mengalami peningkatan maka ROA akan naik yang berarti bahwa kinerja keuangan akan meningkat.

Hasil penelitian ini sesuai dengan hipotesis dan penelitian yang dilakukan oleh Harahap (2017) dan Arshad et al (2012) yang menyatakan bahwa Islamic Social Reporting (ISR) berpengaruh terhadap kinerja keuangan yang diproksikan dengan Return On Asset (ROA), yang menemukan bahwa kebaikan perusahaan perbankan melalui pengungkapan tanggung jawab sosial ditanggapi positif oleh masyarakat yang tercermin dari adanya hubungan signifikan dan positif antara kinerja sosial dan kinerja keuangan.

Hal ini membuktikan bahwa investor sudah beorientasi jangka panjang dan mempertimbangkan pengungkapan tanggung jawab sosial didalam melakukan investasi pada perusahaan perbankan tahun 2012-2016. Dan dengan diterbitkannya UU No.21 Tahun 2008 pasal 7 yang menyatakan bahwa bentuk badan hukum bank syariah adalah Perseroan Terbatas sehingga dalam hal tanggung jawab sosial dan lingkungan bank syariah harus mengacu pada UU No.40 Tahun 2007 yang dalam penelitian ini ternyata mempengaruhi aktivitas pengungkapan tanggung jawab sosial pada perusahaan perbankan. Selain itu, Pengungkapan tanggungjawab sosial (ISR) ini merupakan variabel yang menunjukkan seberapa besar pertanggungjawaban sosial perusahaan kepada publik. Dimana setiap agenda kegiatan dalam ISR mampu membantu perusahaan dalam menjaga citranya kepada publik. Sehingga kedepannya akan menarik perhatian para investor untuk menanamkan modalnya pada perusahaan. Oleh karena itu semakin banyak perusahaan mengungkapkan pertanggungjawaban sosialnya diharapkan akan mempengaruhi Profitabilitas (ROA).

\section{Pengujian Pengaruh Islamic Social Reporting (ISR) terhadap Return on Equity (ROE)}

Hasil pengujian variabel menunjukkan bahwa variabel Islamic Social Reporting (ISR) mempunyai nilai signifikan sebesar 0,032 $(0,032<0,05)$ yang berarti bahwa variabel Islamic Social Reporting (ISR) berpengaruh signifikan positif terhadap Return On Equity (ROE). Hasil ini konsisten dengan hipotesis awal yang menyatakan variabel ISR berpengaruh positif signifikan terhadap ROE. Sehingga ISR dapat digunakan untuk memprediksi ROE dengan arah koefisien positif, artinya jika ISR mengalami peningkatan maka ROE akan naik yang berarti bahwa kinerja keuangan akan meningkat. Sebaliknya jika pengungkapan ISR menurun maka kinerja keuangan perusahaan juga akan turun. Hal ini bermakna bahwa perusahaan yang memiliki kinerja keuangan yang tinggi adalah perusahaan memiliki tanggung jawab sosial yang tinggi, hal ini dapat dilihat melalui laporan tahunan perusahaan dan jumlah dana zakat yang disalurkan perusahaan. Kegiatan sosial kemasyarakatan dibidang kesehatan dan lingkungan serta dalam peningkatan kualitas hidup masyarakat miskin melalui program wirausaha yang dilakukan bank akan memberikan citra positif bagi perusahaan. Selain itu penyaluran dana zakat untuk golongan yang telah ditetapkan oleh syarat juga turut membangun kepercayaan masyarakat yang pada akhirnya perusahaan dalam hal ini Bank Umum Syariah mendapatkan legitimasi dari masyararakat. 
Hasil penelitian ini sesuai dengan hipotesis dan penelitian yang dilakukan oleh Wardani (2016) dan Riswanti (2017) yang menyatakan bahwa Islamic Social Reporting (ISR) berpengaruh terhadap kinerja keuangan yang diproksikan dengan Return On Equity (ROE). Dalam kurun waktu 2012 sampai dengan 2016 nilai ROE dibeberapa bank Syariah memang fluktuatif, tetapi dimbangi dengan kenaikan nilai ROE pada beberapa bank yang semakin baik naik misalnya Bank BNI Syariah dan Bank BCA Syariah. Hal ini membuktikan bahwa pelaksanaan tanggung jawab sosial ini menyebabkan perusahaan mengeluarkan biaya tambahan yang tidak sedikit jumlahnya. Pengeluaran akibat biaya ini tentu akan mempengaruhi perolehan laba perusahaan.

\section{SIMPULAN}

Penelitian ini bertujuan menguji pengaruh variabel Islamic Social Reporting (ISR) terhadap Kinerja Keuangan. Berdasarkan hasil analisis yang telah dilakukan, maka dapat disimpulkan bahwa pengungkapan ISR berpengaruh signifikan positif terhadap kinerja keuangan baik diproksikan dengan ROA maupun ROE.

Penelitian ini masih memiliki beberapa keterbatasan yang perlu diperhatikan oleh peneliti selanjutnya. Beberapa keterbatasan tersebut antara lain: sampel yang digunakan dalam penelitian ini adalah perusahaan perbankan syariah sehingga sampel yang digunakan jumlahnya sedikit dan menghasilkan nilai terlalu kecil, dan Variabel kinerja keuangan dalam penelitian ini diukur dengan 2 rasio yaitu Return On Asset (ROA) dan Return On Equity (ROE) saja, masih ada ukuran variabel kinerja keuangan selain ROA dan ROE.

Berdasarkan keterbatasan penelitian ini, maka perlu dilakukan penyempurnaan penelitian selanjutnya. Adapun sarana untuk peneliti selanjutnya adalah penelitian selanjutnya menggunakan perusahaan yang terdaftar di Jakarta Islamic Index (JII) sehingga memperoleh sampel yang lebih banyak, dan menambah kinerja keuangan lebih luas dengan menggunakan Tobin'Q atau lainnya.

\section{DAFTAR PUSTAKA}

Ahmad, Khaliq. (2002). Islamic Ethics in a Changing Environment for Manager, in Abul Hasan and M. Sadeq. Ethics in Business and Management: Islamic and Mainstream Approaches. London: Asean Academic Press.

Dendawijaya, Lukman. (2009). Manajemen Perbankan. Jakarta: Ghalia Indonesia.

Djakfar, Muhammad. (2007). Etika Bisnis dalam Perpektif Islam. Malang: UIN-Maliki Press.

Ermayanti, Dwi. (2009). Kinerja Keuangan Perusahaan. (http://www.dwiermayanti.wordpress.com).

Fitria dan Hartanti, D. (2010). Islam dan Tanggung Jawab Sosial : Studi Perbandingan Pengungkapan Berdasarkan Global Reporting Initiative Indeks dan Islamic Social Reporting Indeks. Simposium Nasional Akuntansi XIII Purwokerto. 
Gray, R., Javad, M., Power, David M., dan Sinclair, Donald C. (2001). Social and Environmental Disclosure, and Corporate Characteristic: A Research Note and Extension. Journal of Business Finance and Accounting Vol. 28 No. 3 (2001).

Ghozali, Imam dan Chariri, A. (2007). Teori Akuntansi. Semarang: Badan Penerbit Universitas Diponegoro.

Hadi, Nor. (2011). Corporate Sosial Responsibility. Yogyakarta: Graha Ilmu.

Haniffa, Ros. (2002). Social Reporting Disclosure: An Islamic Perspective. Indonesian Management \& Accounting Research Vol. 1 No. 2 July 2002 h. 128-146.

Haniffa, R. dan Hudaib, M. (2007). Exploring the ethical identity of Islamic Banks via communication in annual reports. Journal of Business Ethics Vol. 76. No. 1 (2007).

Harsanti, Ponny. (2011). Corporate Social Responsibility Dan Teori Legitimasi. Jurnal Fakultas Ekonomi Universitas Muria Kudus.

Heal, Geoffrey. dan Garret Paul. (2004). Corporate Social Responsibility, An Economic and Financial Framework. Finance and Economics National Bureau of Economic Research (NBER) Vol. 1.

Hendra, Titisari Kartika. (2010). Corporate Social Responsibility (CSR) dan Kinerja Perusahaan. Simposium Nasional Akuntansi XIII, Purwokerto. https:/ / www.republika.co.id/berita/ekonomi/syariahekonomi/17/10/14/ox rm31415-ini-yang-buat-peluang-pertumbuhan-keuangan-syariah-masihsangat-besar (diakses tanggal 31 Januari 2018).

Jannah, Awalya Ma'rifatul, dan Asrori. (2016). Pengaruh GCG, Size, Jenis Produk dan Kepemilikan Saham Publik terhadap Pengungkapan ISR. Accounting Analysis $\begin{array}{llllll}\text { Journal } & \text { Vol. } & 5 & \text { No. } & 1 & \text { (2016). }\end{array}$ https://journal.unnes.ac.id/sju/index.php/aaj/article/view/9758

Khoirudin, Amirul. (2013). Corporate Governance dan Pengungkapan Islamic Social Reporting pada Perbankan Syariah di Indonesia. Skripsi. Universitas Negeri Semarang.

Othman, R., Thani, Azlan Md., dan Ghani, Erlane K. (2009). Determinants of Islamic Social Reporting Among Top Shariah-Approved Companies in Bursa Malaysia. Resarch Journal of International Studies Issue 12 (October 2009). http:/ / lela.stiemj.ac.id/wp-content/uploads/Islamic-social-reporting-Kel6.pdf

Rosiana, Rita, Arifin, Bustanul, dan Hamdani, Muhammad. (2015). Pengaruh Ukuran Perusahaan, Profitabilitas, Leverage, dan Islamic Governance Score Terhadap Pengungkapan Islamic Social Reporting (Studi Empiris Pada Bank Umum Syariah 
Di Indonesia Tahun 2010-2012). Esensi: Jurnal Bisnis dan Manajemen Vol. 5 No. 1 April 2015. http://journal.uinjkt.ac.id/index.php/esensi/article/view/2334

Rosiliana, K., Yuniarta, G. A., dan Darmawan, N. A. S. (2014). Pengaruh Corporate Social Responsibility Terhadap Kinerja Keuangan Perusahaan (Studi Empiris Pada Perusahaan LQ45 di Bursa Efek Indonesia Periode 2008-2012). Jurnal Ilmiah Mahasiswa Akuntansi Universitas Pendidikan Ganesha Vol. 2 No. 1 (2014). https://ejournal.undiksha.ac.id/index.php/S1ak/article/view/3452

Rivai, Veithzal dan Basri, Ahmad Fauzi. (2004). Performance Appraisal: Sistem yang Tepat untuk Menilai Kinerja Karyawan dan Meningkatkan Daya Saing Perusahaan. Jakarta: PT. Grorontalo Persada.

Tilling, M.V. (2004). Refinements to Legitimacy Theory in Social and Environmental Accounting. Commerce Research Paper Series.

Widiawati, S. dan Raharja, S. (2012). Analisis Faktor-Faktor Yang Mempengaruhi Islamic Social Reporting Perusahaan-Perusahaan Yang Terdaftar Pada Daftar Efek Syariah Tahun 2009-2011. Diponegoro journal of Accounting Vol. 1 (1) Tahun 2012.

Wibisono, Yusuf. (2007). Membedah Konsep \& Aplikasi CSR (Corporate Social Responsibility. Jakarta: PT Gramedia. 
Susi Retnaningsih, Widi Hariyanti, E Titiek Puji Astuti

Halaman ini sengaja dikosongkan 